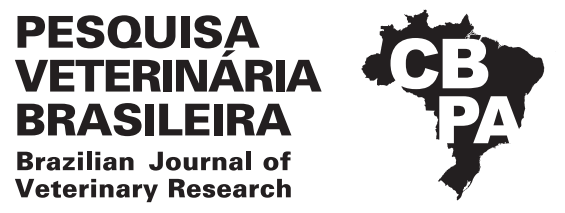

Pesq. Vet. Bras. 38(8):1549-1553, agosto 2018 DOI: 10.1590/1678-5150-PVB-5550

Original Article

Animais de Produção/Livestock Diseases

ISSN 0100-736X (Print)

ISSN 1678-5150 (Online)

\title{
Nitrate and nitrite poisoning in sheep and goats caused by ingestion of Portulaca oleracea ${ }^{1}$
}

\author{
João G. Simões², Rosane Maria T. Medeiros², Márcia A. Medeiros², \\ Robério G. Olinda ${ }^{2}$, Antônio Flávio M. Dantas ${ }^{2}$ and Franklin Riet-Correa ${ }^{2,3 *}$
}

\begin{abstract}
Simões J.G., Medeiros R.M.T., Medeiros M.A., Olinda R.G., Dantas A.F.M. \& Riet-Correa F. 2018. Nitrate and nitrite poisoning in sheep and goats caused by ingestion of Portulaca oleracea. Pesquisa Veterinária Brasileira 38(8):1549-1553. Hospital Veterinário, Centro de Saúde e Tecnologia Rural, Universidade Federal de Campina Grande, Campus de Patos, PB 58708-110, Brazil. E-mail: frcorrea@inia.org.uy

Three outbreaks of poisoning by Portulaca oleracea were reported in sheep and goats in Northeast Brazil. In the first outbreak, 8 out of 20 sheep were affected and later died. In the second outbreak, three goats and one sheep died out of a flock of 30 animals that included both species. In the third outbreak, two out of 19 sheep were affected, and they recovered after a treatment of $2 \%$ methylene blue at a dose of $4 \mathrm{mg} / \mathrm{kg}$ body weight. In the first and second outbreaks, the animals ingested P. oleracea after it was cut and offered in feeders. In the third outbreak, the flock was grazing in an area that had been invaded by the plant. To determine the toxicity, P. oleracea was administered experimentally at a dose of $80 \mathrm{~g} / \mathrm{kg}$ of body weight to seven sheep, weighing $19-30 \mathrm{~kg}$. One control sheep received green grass. One to four hours after P. oleracea ingestion, the animals showed clinical signs of poisoning characterized by cyanotic mucous membranes, bloat, ruminal $\mathrm{pH}$ of 8-9, pollakiuria, aerophagia, involuntary movements of the upper lip, apathy, tachypnea and tachycardia. Five animals recovered, including one that was treated with $1 \%$ methylene blue, and two animals died. During necropsy, the mucous membranes were brownish, and the blood was dark brown. Diphenylamine tests of the plant and of rumen contents were positive for nitrates. Positive results for nitrates were also found in 24 samples of P. oleracea that were collected in different places in the states of Pernambuco and Paraíba. We conclude that $P$. oleracea accumulates nitrates at toxic levels and may cause poisoning in sheep and goats.
\end{abstract}

INDEX TERMS: Poisonous plants, nitrate, nitrite, poisoning, sheep, goats, Portulaca oleracea, methemoglobinemia, toxic plants, plant poisoning, Portulacaceae, toxicoses.

RESUMO-- [Intoxicação por nitratos e nitritos em ovinos
e caprinos causada pela ingestão de Portulaca oleracea.]
Relatam-se três surtos de intoxicação por Portulaca oleracea
em ovinos e caprinos no Nordeste do Brasil. No primeiro
surto morreram oito de 20 ovinos. No segundo morreram
três caprinos e um ovino de um total de 30 animais das duas
espécies. No terceiro surto foram afetadas duas ovelhas de um
rebanho de 19 animais, que se recuperaram após o tratamento

\footnotetext{
${ }^{1}$ Received on July 27, 2017.

Accepted for publication on August 13, 2017.

${ }^{2}$ Unidade Acadêmica de Medicina Veterinária (UAMV), Centro de Saúde e Tecnologia Rural (CSTR), Universidade Federal de Campina Grande (UFCG), Av. Universitária s/n, Bairro Santa Cecília, Patos, PB 58700-970, Brazil.

${ }^{3}$ National Institute for Agricultural Research (INIA), La Estanzuela, CP 70.000, Colonia, Uruguay. *Corresponding author: frcorrea@inia.org.uy, franklinrietcorrea@gmail.com
}

com azul de metileno a $2 \%$ na dose de $4 \mathrm{mg} / \mathrm{kg} /$ vivo. Nos surtos 1 e 2 os animais ingeriram P. oleracea cortada e oferecida no coxo e no surto 3 estavam pastoreando em uma área invadida pela planta. Para determinar a toxicidade de P. oleracea foram utilizados oitos ovinos, sendo sete experimentais e um controle, com peso entre 19 e $30 \mathrm{~kg}$. A planta foi administrada por via oral, na dose de $80 \mathrm{~g} / \mathrm{kg} /$ peso corporal. 0 animal controle recebeu capim verde e concentrado. Entre uma a quatro horas após a ingestão da planta os animais apresentaram sinais clínicos caracterizados por mucosas cianóticas, timpanismo gasoso, $\mathrm{pH}$ ruminal de 8-9, polaquiúria, aerofagia, movimentos involuntários do lábio superior, apatia, taquipnéia e taquicardia. Cinco animais se recuperaram, incluindo um que foi tratado com azul de metileno a $2 \%$, e dois morreram. Na necropsia observaram-se mucosas de coloração marrom e sangue marrom escuro. 0 teste de difenilamina realizado na planta 
e no conteúdo ruminal foi positivo para nitratos. Resultados positivos para nitratos foram detectados em 24 amostras coletadas em diferentes locais dos estados de Pernambuco e Paraíba. Conclui-se que . oleracea acumula nitratos em níveis tóxicos, e quando ingerida por ovinos e caprinos pode provocar intoxicação e morte.

TERMOS DE INDEXAÇÃO: Plantas tóxicas, nitrato, nitrito, ovinos, caprinos, Portulaca oleracea, meta-hemoglobinemia, intoxicação por plantas, Portulacaceae, toxicoses.

\section{INTRODUCTION}

Portulaca oleracea (Portulacaceae family, common name: common purslane; locally known as beldroega in Brazil) is considered a nitrate- or oxalate-containing plant (Everist 1974, Rahman et al. 2013); however, we found no scientific literature describing nitrate and nitrite poisoning due to the consumption of this plant. On the other hand, the administration of either P. oleracea to goats in doses of $5 \mathrm{~g} / \mathrm{kg}$ of body weight or ad libitum for periods of 15 to 40 days caused bloat, diarrhea, loss of appetite, drowsiness, weakness of the limbs and recumbence followed by death within days, with renal and hepatic lesions (Obied et al. 2003).

Portulaca oleracea is mentioned by farmers in the state of Rio Grande do Norte, in Northeast Brazil, as a cause of bloat and other digestive disorders in cattle (Silva et al. 2006). However, several samples of $P$. oleracea, from different Brazilian states, were non-toxic to cattle when administered at daily doses of 11 to $70 \mathrm{~g} / \mathrm{kg}$ of body weight for a period of one to five days (Tokarnia et al. 2012). The aims of the present study were as follows: to report outbreaks of poisoning by P. oleracea in the States of Pernambuco and Paraíba; to describe the experimental reproduction of the intoxication; to demonstrate that the toxicosis is caused by high concentrations of nitrites/nitrates in the plant; and to examine the presence of nitrites/nitrates in plant samples from multiple locations in the states of Pernambuco and Paraíba.

\section{MATERIALS AND METHODS}

Epidemiological data of spontaneous poisoning by Portulaca oleracea were collected during visits to two farms in the state of Pernambuco, where suspected poisoning outbreaks by a plant popularly known as beldroega were reported. One outbreak occurred in 1997 at a farm located in the municipality of São José do Egito. Two additional outbreaks occurred in 2013 and 2015 at a farm located in the municipality of Tabira. In the 2015 outbreak, the affected goats were examined and treated for nitrite poisoning by administering $2 \%$ methylene blue at a dose of $4 \mathrm{mg} / \mathrm{kg}$ of body weight.

The experimental reproduction of the poisoning was performed from July to August 2012. The P. oleracea plant was collected at the farm where the first outbreak of the poisoning was reported. A voucher specimen was collected, pressed, dried, and sent to the Herbarium of the Health Center and Rural Technology at the Federal University of Campina Grande (UFCG), Campus of Patos, Paraíba, for botanical identification.

After being dewormed, eight 2-year-old, hairless crossbred sheep were adapted for a week in the stalls where the experiment was conducted; the sheep ingested concentrated rations in an amount equivalent to $1 \%$ of their live weight, along with Cynodon dactylon (Tifton) hay and water ad libitum. Before the beginning of the experiment, all animals were fasted for 12 hours and were weighed afterwards to determine the dose of $P$. oleracea to be administered.

$P$. oleracea was collected between 5:00 and 6:00am in a 6 hectare paddock that had been invaded by the plant. Immediately, the plant samples were transported to the Veterinary Hospital of the Federal University of Campina Grande in Patos, Paraíba, $75 \mathrm{~km}$ away from the farm. Immediately after arrival, the plant was weighed and administered to seven sheep, with live weights between 19 and $30 \mathrm{~kg}$, in a single dose of $80 \mathrm{~g} / \mathrm{kg}$ of body weight. P. oleracea was supplied to the sheep through the feed to allow the spontaneous consumption of the plant by each animal according to its weight. When the animals did not ingest $P$. oleracea spontaneously, the plant was administered manually by putting small amounts into their mouths and stimulating chewing and swallowing. The control sheep received the same diet that it had been administered before the experiment.

The animals were examined for rectal temperature, heart rate, respiratory frequency and ruminal movements. Blood was collected in EDTA tubes for the determination of serum aspartate aminotransferase (AST) and gamma-glutamyl transferase (GGT) activities. Rumen content was obtained through an orogastric tube and examined for sedimentation, flotation, $\mathrm{pH}$ and presence of rumen protozoa.

The animals that died were necropsied, and samples of organs from the thoracic and abdominal cavities and from the central nervous system were collected, fixed in $10 \%$ buffered formalin, embedded routinely in paraffin, cut into $5 \mu \mathrm{m}$ sections, and stained with hematoxylin and eosin (HE) for histopathological examination. The nitrate detection was determined by the diphenylamine test (Medeiros et al. 2003) in samples of the plant and in the blood and rumen contents of the intoxicated sheep. One experimental sheep and two spontaneously affected sheep were treated with a $2 \%$ methylene blue solution, as mentioned previously.

In March 2014, P. oleracea samples were collected in the state of Paraíba, in the municipalities of Monteiro, Patos, São José do Bonfim and Teixeira, and in the state of Pernambuco, in the municipalities of Santa Terezinha, Tabira, Brejinho and São José do Egito. Three samples were collected in each municipality, for a total of 24 samples. All samples were collected in paddocks with the following characteristics: the presence of grazing ruminants; pastures had a variety of plants and no dominant species; and no history of previous cases of poisoning. All samples, except those from Monteiro, were collected during the dry period.

\section{RESULTS}

\section{Spontaneous poisoning}

The first outbreak in sheep was reported in 1997 at a farm located at $07^{\circ} 28^{\prime} 44^{\prime \prime} \mathrm{S}$ and $37^{\circ} 16^{\prime} 28^{\prime \prime} \mathrm{W}$, in the city of São José do Egito, Pernambuco state. The plant claimed by the farm owner to be the cause of the disease was identified as Portulaca oleracea L. of the Portulacaceae family (Fig.1). A voucher specimen was deposited at the Herbarium of the Center for Health and Rural Technology, Campus of Patos, Paraíba, Brazil, with the registration number 3896. The outbreak occurred at the end of a long drought period. Due to the reduced supply of native pasture (caatinga) forage at the time, the animals were fed in a corral with forage cactus (Opuntia ficus indica) and elephant grass (Pennisetum purpureum). Five days after a rainfall, $P$. oleracea sprouted and was cut by the farmer, who then administered the plants in a feeder to 20 sheep. Eleven sheep showed signs of intoxication and eight sheep died approximately two hours after ingesting 


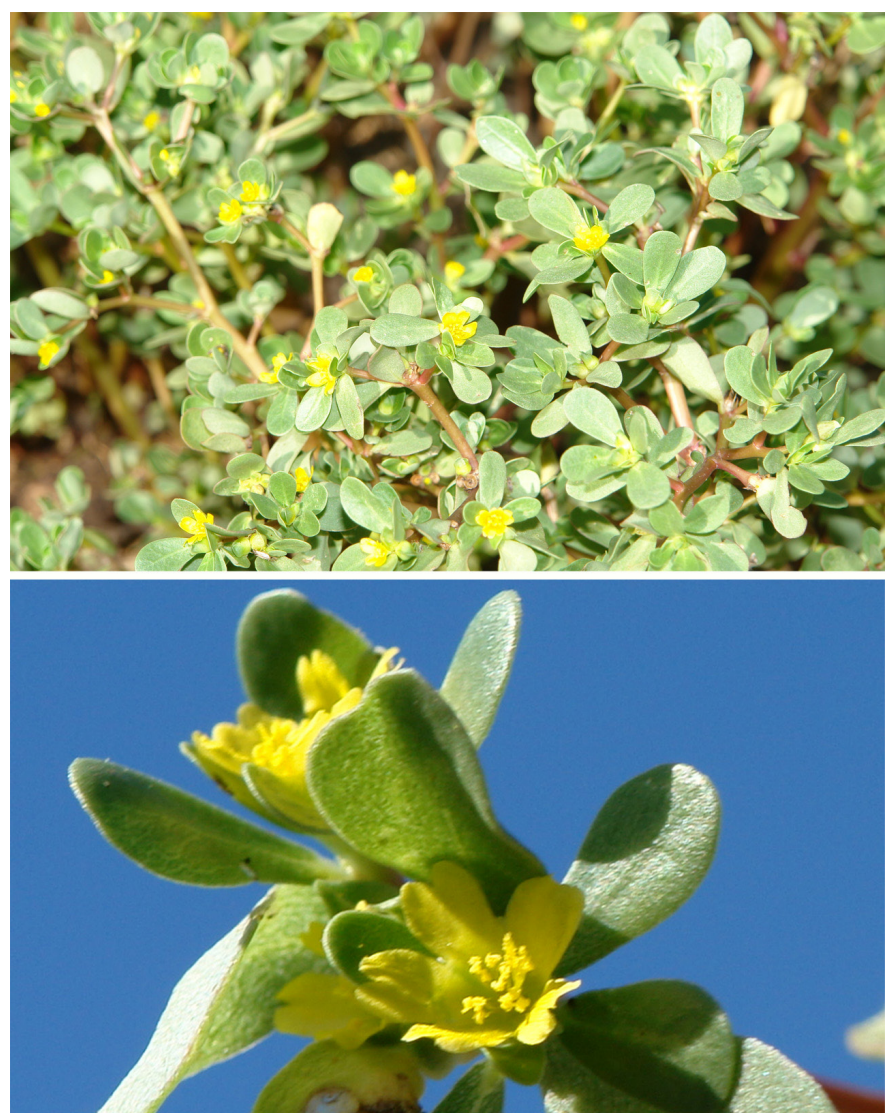

Fig.1. Portulaca oleracea in the municipality of Patos, Paraíba state, Brazil.

the plant. The clinical signs described by the farmer were weakness, bloat, restlessness, increased urinary frequency, and recumbence, followed by death. Plant samples tested positive for nitrates/nitrites using the diphenylamine test.

Another two outbreaks of poisoning by P. oleracea occurred in March 2013 and December 2015 at a farm in the municipality of Tabira (at $7^{\circ} 39^{\prime} 32.8^{\prime \prime} \mathrm{S}$ and $37^{\circ} 32^{\prime} 27.1^{\prime \prime} \mathrm{W}$ ), Pernambuco state. The first outbreak occurred at the start of the rainy season, affecting a herd of 30 animals, including sheep and goats. The mean annual rainfall in the region is $806 \mathrm{~mm}$ (IPA 2012, INMET 2016), but during 2012, rainfall decreased to $289.5 \mathrm{~mm}$, and from January to March 2013, rainfall was only $69 \mathrm{~mm}$. The plants supplied to the animals were harvested from a paddock fertilized with manure from a corral. Three hours after ingestion of the plant, three goats and one sheep presented with aerophagia, abdominal pain, bloat, falls, lateral deviation of the head, obtundation, and sternal recumbence (Fig.2A), followed by death. The second outbreak occurred in December 2015 in a flock of 21 sheep. The animals were grazing in an area planted with tomatoes (Solanum lycopersicum). The flock was moved to the paddock because there was a shortage of water and because it was impossible to continue irrigating the tomatoes. Two pregnant ewes presented with bloat, apathy, aerophagia, uncoordinated gait and cyanotic mucous membranes. Both ewes were treated with $2 \%$ methylene blue at a dose of $4 \mathrm{mg} / \mathrm{kg}$ of body weight. One ewe recovered within six hours, and the other ewe recovered within 24 hours. One ewe aborted a week after treatment, and the other ewe gave birth to two healthy lambs. Plant samples collected at the farms tested positive for nitrates using the diphenylamine test.

In 2013, during visits to five farms in the municipalities of São José do Egito in Pernambuco, and of São José do Bonfim in Paraíba, farmers reported the occurrence of a similar disease in sheep after the ingestion of $P$. oleracea.

\section{Experimental poisoning}

All animals showed temperature, heart and respiratory rates, and ruminal movements within normal ranges before P. oleracea ingestion. Clinical signs of poisoning were observed 20-30 minutes after plant ingestion, starting with involuntary movements of the upper lip (Sheep 1, 2, 5, 6 and 7), loud ruminal movement sounds (Sheep 1, 2, 5 and 7), bloat (Sheep 3 and 4), aerophagia (Sheep 2, 4, 5 and 6), temperature of $40.5^{\circ} \mathrm{C}$ (Sheep 5), and pollakiuria (Sheep 1, 2, 3, 5 and 7). Abdominal pain (Sheep 3 and 5), dysphagia (Sheep 5), decreased ruminal movements (Sheep 4 and 5), and salivation (Sheep 6) were also observed. Sheep 5, 6 and 7 showed signs of cellular anoxia, including obtundation, tachycardia, tachypnea, staggering gait, positive jugular pulse, opisthotonos, bruxism, and cyanotic mucous membranes (Fig.2B). In Sheep 5 and 6, the following were observed before death: severe dyspnea with neck extension, nasal discharge, jugular vein engorgement, emesis and sternal recumbence, followed by lateral recumbence; death occurred approximately 12 hours after plant ingestion. Sheep 1-4 recovered without treatment in approximately 12 hours. For Sheep 3 and 4, a gastric tube was used to alleviate bloat. After showing muscle weakness, increased frequency of urination, and cyanosis, Sheep 7 was treated intravenously with $2 \%$ methylene blue at a dose of $4 \mathrm{mg} / \mathrm{kg}$ of body weight. Thirty minutes after treatment, the sheep had recovered and was drinking and eating normally. Sheep 8 (control) remained healthy during the experiment.

In the poisoned sheep, serum activities of AST and GGT were within the normal range for the species. A ruminal fluid analysis revealed an increase in $\mathrm{pH}$ between 8-9 and a decrease in the number of medium and large protozoa in all animals.

Necropsies of Sheep 5 and 6 were performed immediately after death. The blood of these animals was dark brown and did not coagulate. In all organs, the blood vessels were markedly engorged with brown stained blood (Fig.2C). The muscles, lungs and brain showed a brownish surface. No significant histological lesions were observed. The diphenylamine tests that were performed in P. oleracea and rumen contents were positive within 10 seconds (Fig.2D).

\section{Results of the diphenylamine tests in Portulaca oleracea samples}

All 24 P. oleracea samples that were collected had strongly positive results within 10 seconds using the diphenylamine test.

\section{DISCUSSION}

The following results demonstrated that Portulaca oleracea caused nitrate and nitrite poisoning in sheep and goats in Northeast Brazil: the clinical signs and lesions that were observed during necropsy; the experimental reproduction of the poisoning with clinical signs similar to those reported in spontaneous cases; the results of the diphenylamine tests; and the recovery of the intoxicated animals by methylene 

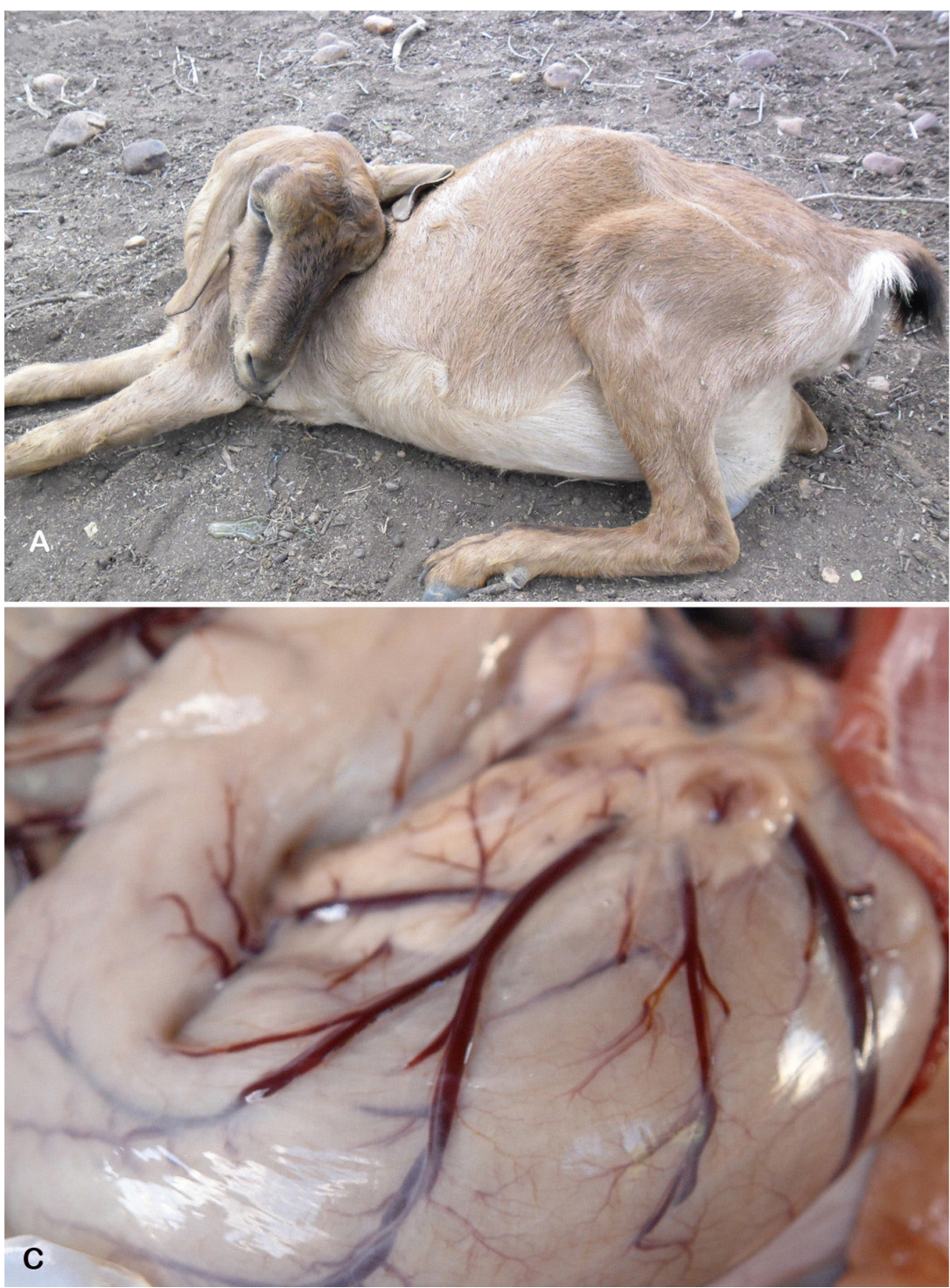
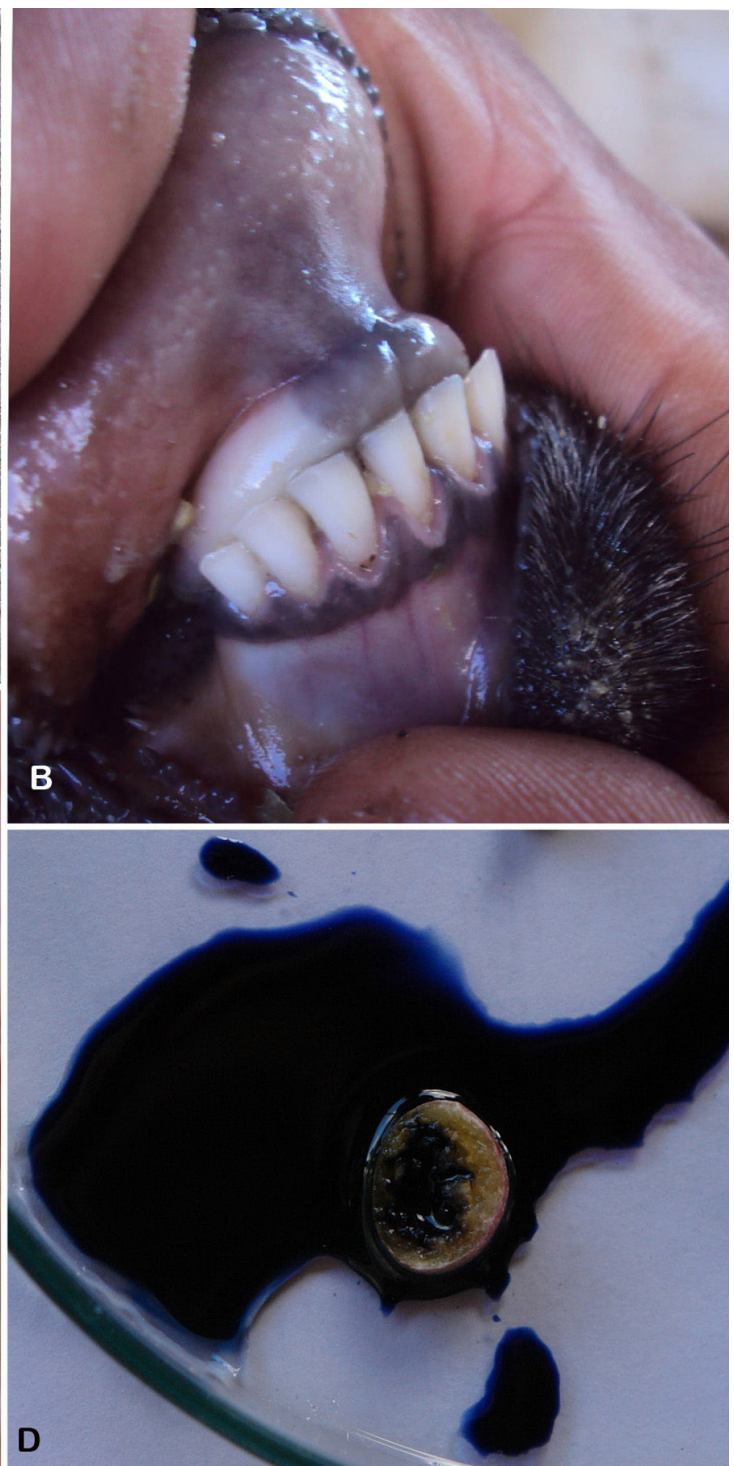

Fig.2. Portulaca oleracea poisoning in sheep and goats. (A) Goat spontaneously poisoned by P. oleracea, showing sternal recumbence, obtundation and bloat. (B) Oral mucosa of Sheep 6, experimentally poisoned by P. oleracea, showing severe cyanosis. (C) Abomasum with vessels dilated with brownish blood. (D) Diphenylamine test in a P. oleracea sample. The reaction was positive in less than 10 seconds.

administration. In Brazil, nitrate and nitrite poisoning have been diagnosed in cattle that were fed with Pennisetum purpureum and Echinochloa polystachya (Medeiros et al. 2003) in the State of Paraíba, and with oat (Avena sativa) and/or ryegrass (Lolium multiflorum) in the State of Santa Catarina (Jönck et al. 2013).

High doses of $P$. oleracea ( $80 \mathrm{~g} / \mathrm{kg}$ of body weight) were necessary to produce the experimental poisoning, suggesting that as in other nitrate-containing plants, the ingestion of large amounts of $P$. oleracea in a short period of time is an important factor in the occurrence of the poisoning (Poore et al. 2001). Other factors associated with nitrate and nitrite poisoning include the occurrence of the disease after prolonged periods of drought and after fertilization with manure (Fraser 1996), both of which were also observed in the outbreaks described in this report. However, all samples of $P$. oleracea that were collected in the dry season and in the rainy season showed strong positive results on the diphenylamine test, suggesting that, at least in Northeast Brazil, the plant is a nitrate accumulator regardless of environmental conditions. Poor nutrition has also been associated with nitrate and nitrite poisoning (Robson 2003). This condition, which is very common in Northeast Brazil due to long periods of drought, could have favored the occurrence of the disease in the outbreaks reported in the present study.

Some of the observed clinical signs, including breathing difficulties, dyspnea, and cyanotic mucous membranes due to methemoglobinemia, are characteristic of nitrite poisoning. The digestive signs, including bloat and decreased ruminal movements, are probably due to the relaxation of the smooth muscles of the gastrointestinal tract. It has been suggested that nitrates may reduce the spontaneous motility of the esophagus and pre-stomachs of ruminants (Robertson \& Robertson 1996). Nitrates may also cause irritation in the 
digestive tract, as well as urinary disorders that lead to frequent urination (Obied et al. 2003), as observed in the experimentally poisoned sheep.

Nitrate and nitrite poisoning have been implicated as a cause of abortion in ruminants (Radostits et al. 2007). In the abovementioned 2015 outbreak, one of the two treated sheep aborted seven days after recovering from P. oleracea poisoning. Although the adult sheep recovered, the abortion probably occurred because the fetus was more susceptible. It has been suggested that, with nitrite poisoning, the cause of fetal death is severe anoxia (Radostits et al. 2007).

Both the clinical signs and the macroscopic changes observed in the present study were similar to those that have been described in nitrate and nitrite poisoning in sheep (Radostits et al. 2007), goats (Pugh 2004) and cattle (Medeiros et al. 2003, Jönck et al. 2013). Cyanosis along with brownish dark blood and muscles are findings that suggest nitrate and nitrite poisoning when a necropsy is performed immediately after death. However, it should be cautioned that, a few hours after death, methemoglobin changes to hemoglobin, and the dark brown color of the blood, carcass and muscle disappears (Tokarnia et al. 2012). The absence of microscopic lesions has also been reported in cases of nitrate and nitrite poisoning in ruminants (Riet Alvariza 1993, Medeiros et al. 2003, Radostits et al. 2007, Tokarnia et al. 2012).

During the experiment, the recovery of four sheep a few hours after they showed clinical signs of poisoning may be because some animals can tolerate up to a $50 \%$ conversion of hemoglobin to methemoglobin and because death only occurs when the conversion exceeds 80\% (Robson 2003). Nitrate and nitrite poisoning in sheep and goats had not been reported previously in Brazil. Among ruminants, sheep are more efficient in converting nitrite to ammonia and are therefore less susceptible to poisoning than cattle, which could possibly explain the lower incidence of nitrite poisoning in sheep (Robson 2003).

\section{CONCLUSION}

Portulaca oleracea is a plant that accumulates nitrates and causes nitrate and nitrite poisoning in sheep and goats in the semiarid region of Northeast Brazil.

Acknowledgements.- This investigation was financially supported by the National Institute of Science and Technology for the Control of Poisonous Plants (INCT), CNPq, and grant 573534/2008-0.

\section{REFERENCES}

Alvariza F.R. 1993. Intoxicación por nitratos y nitritos, p.291-297. In: RietCorrea F., Méndez M.C. \& Schild A.L. (Eds), Intoxicações por Plantas e Micotoxicoses em Animais Domésticos. Editorial Agropecuaria Hemisferio Sur, Montevideo.
Everist S.L. 1974. Poisonous Plants of Australia. Angus and Robertson, Sydney, 488p.

Fraser M.C. 1996. Manual Merck de Veterinária: um manual de diagnóstico, tratamento, prevenção e controle de doenças para o veterinário. 7a ed. Roca, São Paulo, p.2048-2051.

INMET 2016. Normais Climatológicas. Instituto Nacional de Meteorologia, Brasília. Available at <http://www.inmet.gov.br/portal/index.php?r=clima/ normaisClimatologias> Accessed on May 29, 2016.

IPA 2012. Sessão de Índices Pluviométricos. Instituto Agronômico de Pernambuco, Recife. Available at <http://www.ipa.br/indice_pluv.php> Accessed on June 29, 2015

Jönck F., Gava A., Traverso S.D., Lucioli J., Furlan F.H. \& Gueller E. 2013. Intoxicação espontânea e experimental por nitrato/nitrito em bovinos alimentados com Avena sativa (aveia) e/ou Lolium spp. (azevém). Pesq. Vet. Bras. 33(9):1062-1070. <http://dx.doi.org/10.1590/S0100736X2013000900003>

Medeiros R.M.T., Riet-Correa F., Tabosa I.M., Silva Z.A., Barbosa R.C., Marques A.V.M.S. \& Nogueira F.R.B. 2003. Intoxicação por nitratos e nitritos em bovinos por ingestão de Echinochloa polystachya (capim-mandante) e Pennisetum purpureum (capim elefante) no sertão da Paraíba. Pesq. Vet. Bras. 23(1):17-20.<http://dx.doi.org/10.1590/S0100-736X2003000100004>

Obied W.A., Mohamoud E.N. \& Mohamed O.S.A. 2003. Portulaca oleracea (purslane): nutritive composition and clinico-pathological effects on Nubian goats. Small Rum. Res. 48(1):31-36. <http://dx.doi.org/10.1016/ S0921-4488(02)00182-7>

Poore M., Green J., Rogers G., Spivey K. \& Dugan K. 2001. Nitrate Management in Beef Cattle Production Systems. West Virginia University, Morgantown. Available at <http://www.wvu.edu/ agexten/forglvst/Nitrdrot.htm> Accessed on June 1, 2016.

Pugh D.G. 2004. Clínica de Ovinos e Caprinos. Roca, São Paulo, p.139-140.

Radostits O.M., Gay C.C., Blood D.C., Hinchcliff K.W. \& Constable P.D. 2007. Veterinary Medicine: a textbook of the diseases of cattle, horses, sheep, pigs, and goats. 10th ed. W.B. Saunders, Philadelphia, 2065p.

Rahman M.M., Abdullah R.B. \& Wan Khadijah W.E. 2013. A review of oxalate poisoning in domestic animals: tolerance and performance aspects. J. Anim. Physiol. Anim. Nutr. 97(4):605-614. <http://dx.doi. org/10.1111/j.1439-0396.2012.01309.x><PMid:22548678>

Robertson R.M. \& Robertson D. 1996. Drugs used for the treatment of myocardial ischemia, p.848. In: Hardman J.G. \& Linbird L.R. (Eds), Goodman and Gilman's the Pharmacological Basis of Therapeutics. 9th ed. McGrawHill, New York.

Robson S. 2003. Nitrate and Nitrite Poisoning in Livestock, State of New South Wales, agfact A0.9.67. Department of Agriculture, New South Wales, p.1-3. Available at <http://www.dpi.nsw.gov.au/_dataHYPERLINK "http:// www.dpi.nsw.gov.au/_data/assets/pdf_file/0006/111003/nitrateand-nitrite-poisoning-in-livestock.pdf"/assets/pdf_file/0006/111003/ nitrate-and-nitrite-poisoning-in-livestock.pdf> Accessed on July 8, 2014.

Silva D.M., Riet-Correa F., Medeiros R.M.T. \& Oliveira O.F. 2006. Plantas tóxicas para ruminantes e eqüídeos no Seridó Ocidental e Oriental do Rio Grande do Norte. Pesq. Vet. Bras. 26(4):223-236. <http://dx.doi.org/10.1590/ S0100-736X2006000400007>

Tokarnia C.H., Brito M.F., Barbosa J.D., Peixoto P.V. \& Döbereiner J. 2012. Plantas Tóxicas do Brasil. 2ª ed. Editora Helianthus, Rio de Janeiro. 566p. 